\title{
A Century of Ocean Warming on Florida Keys Coral Reefs: Historic In Situ Observations
}

\author{
Ilsa B. Kuffner • Barbara H. Lidz • J. Harold Hudson • \\ Jeffrey S. Anderson
}

Received: 23 May 2014 / Revised: 15 August 2014 / Accepted: 22 August 2014 /Published online: 5 September 2014

(C) The Author(s) 2014. This article is published with open access at Springerlink.com

\begin{abstract}
There is strong evidence that global climate change over the last several decades has caused shifts in species distributions, species extinctions, and alterations in the functioning of ecosystems. However, because of high variability on short (i.e., diurnal, seasonal, and annual) timescales as well as the recency of a comprehensive instrumental record, it is difficult to detect or provide evidence for long-term, sitespecific trends in ocean temperature. Here we analyze five in situ datasets from Florida Keys coral reef habitats, including historic measurements taken by lighthouse keepers, to provide three independent lines of evidence supporting approximately $0.8^{\circ} \mathrm{C}$ of warming in sea surface temperature (SST) over the last century. Results indicate that the warming observed in the records between 1878 and 2012 can be fully accounted for by the warming observed in recent decades (from 1975 to 2007), documented using in situ thermographs on a mid-shore patch reef. The magnitude of warming revealed here is similar to that found in other SST datasets from the region and to that observed in global mean surface temperature. The geologic context and significance of recent ocean warming to coral growth and population dynamics are discussed, as is the future prognosis for the Florida reef tract.
\end{abstract}

Communicated by Wayne S. Gardner

Electronic supplementary material The online version of this article (doi:10.1007/s12237-014-9875-5) contains supplementary material, which is available to authorized users.

I. B. Kuffner $(\bowtie) \cdot$ B. H. Lidz

US Geological Survey, 600 4th Street South, St. Petersburg,

FL 33701, USA

e-mail: ikuffner@usgs.gov

J. H. Hudson

Reef Tech, Inc., 8325 SW 68 Street, Miami, FL 33143, USA

J. S. Anderson

Nature Imagery, Honolulu, HI 96815, USA
Keywords Sea surface temperature - Global climate change . Coral reef degradation $\cdot$ Coral growth $\cdot$ In situ temperature . Florida reef tract

\section{Introduction}

Climate on Earth is ever changing over time, as shown even for the relatively less dynamic Holocene (Poore et al. 2003; Mayewski et al. 2004). However, the human species has moved large quantities of carbon from fossil reservoirs, built over millennia, into the atmosphere and oceans on the timescale of centuries and thus has altered radiative forcing on Earth (Mackenzie and Lerman 2006). The rate of change (both in carbon distribution and global temperature) that has been observed in the last 40 years could be unprecedented in the geologic record (Hansen et al. 2006; Honisch et al. 2012); however, environmental proxies of sufficient sampling resolution do not yet exist to answer this question definitively. Most organisms alive today are adapted to the range in temperatures experienced during the Holocene. The best evidence for recent rapid climate change that we presently have is the well-documented, collective biological response to a warmer environment, including changes in timing of life history events, range shifts, and local extinctions for marine (Poloczanska et al. 2013), freshwater, and terrestrial species on all continents and in all oceans (Parmesan 2006).

Because of the immense thermal inertia of the oceans and the thousand-year timescale of ocean circulation, sea surface temperature (SST) is warming at slower rates compared to air over land and in a spatially heterogeneous pattern (Barnett et al. 2005; Burrows et al. 2011). Humans have measured SST since the invention of the thermometer several centuries ago, but systematic monitoring only began around the turn of the twentieth century (e.g., Vaughan 1918), and surprisingly few long-term, in situ datasets exist (e.g., Winter et al. 1998). Datasets measuring subsurface temperatures in coral reef 
environments are even more scarce (Hudson et al. 1991), but starting in the 1990s, the deployment of fixed sensors (Ogden et al. 1994) and accurate, yet inexpensive, temperature loggers has lessened this data gap. Also, SST has been monitored remotely from space since the 1980s with satellite-mounted radiometers that produce infrared imagery (Good et al. 2007).

Coral reefs are an ecosystem especially sensitive to increases in ocean temperature. Above-normal temperatures are stressful to reef-building corals because of the stenothermal nature of the symbiosis between corals and the dinoflagellates (zooxanthellae) that provide up to $95 \%$ of the metabolic demands of the coral (Muscatine 1990). Unusually warm water (as little as $1{ }^{\circ} \mathrm{C}$ above usual summer means) can cause the breakdown of the symbiosis and the mass expulsion of zooxanthellae, referred to as "coral bleaching." One of the first documented coral bleaching episodes occurred in 1971 as a result of unnaturally augmented water temperatures adjacent to an outflow pipe of a power plant cooling system in Hawaii (Jokiel and Coles 1974). Soon thereafter, "natural" coral bleaching was observed on coral reefs in Florida in September 1973 (Jaap 1979), a decade later in the Eastern Pacific (Glynn 1983), and subsequently all over the world (see Oliver et al. (2009) for review). The first welldocumented and truly global-scale bleaching event occurred in 1998 (Wilkinson and Hodgson 1999), and regional bleaching events now occur nearly every year in some parts of the world (Hoegh-Guldberg et al. 2007; Eakin et al. 2009). The increased expanse, severity, and frequency of coral bleaching are thought to be the result of generally rising ocean temperatures superimposed on natural climate oscillations (e.g., the El Niño Southern Oscillation, ENSO). Additionally, climate change may be increasing the intensity (Hansen et al. 2006) and the frequency of extreme El Niño events (Cai et al. 2014).

Having remotely sensed temperature monitoring from space has greatly improved predictive capabilities, allowing for real-time detection of temperature anomalies and early warning of bleaching events (Hu et al. 2009; Eakin et al. 2010). Caution is advised, however, when attempting to derive local, absolute patterns in SST from regionally and globally synthesized satellite data products, especially in nearshore waters typical of coral reef ecosystems. Satellites that measure the temperature of the "skin" of the ocean are unable to measure ambient temperature at depth and thus cannot fully represent the subsurface environs inhabited by reef organisms (Castillo and Lima 2010). Moreover, coral reefs are exposed to significant thermal variability across a range of temporal and spatial scales (Leichter et al. 2006). The shallowness of nearshore waters makes them responsive to heat exchange across the air-water interface (Pitts and Smith 1995) and, in the case of the Florida reefs, to the tidally driven effects of unusually hot or cold, very shallow (2-3-m deep), inland-bay waters (Roberts et al. 1982).
Very few in situ water temperature data exist for the Florida reef tract prior to 1990. Here we present comparable aspects of some published (Vaughan 1918; Hudson et al. 1991) and unpublished (Ogden et al. 1994) data and demonstrate that, as is apparent elsewhere, waters off the Florida Keys warmed about $0.8^{\circ} \mathrm{C}$ since the late $1800 \mathrm{~s}$. We then briefly discuss the implications of ocean warming in light of what is known about coral growth and population fluctuations in the region over the past century and throughout the Holocene.

\section{Materials and Methods}

\section{Temperature Data for the Florida Reef Tract}

Near the end of the nineteenth century, Vaughan (1918) obtained from H.F. Moore (US Bureau of Fisheries) multidecadal records of SST measurements taken by lighthouse keepers in the Florida Keys and Dry Tortugas. The two longest and most complete records are from the lighthouses at Carysfort Reef and Fowey Rocks, constructed in 1852 and 1878 , respectively. Both lighthouses are located approximately $10 \mathrm{~km}$ from shore on the upper Florida Keys outer-shelf reef, in 2 to $4 \mathrm{~m}$ of water (Fig. 1). Data exist for 1878 to 1899 for Carysfort Reef and 1879 to 1912 for Fowey Rocks. Information regarding the protocol used to take the temperature measurements was not published along with the data (10day means of daily measurements; Vaughan 1918), but technology at the time was such that it probably involved a bucket lowered over the side of the lowest platforms of the lighthouses ( $\sim 3 \mathrm{~m}$ above sea level) and a mercury thermometer. While no information was found on the methods used to calibrate the mercury thermometers, the men employed as lighthouse keepers were educated, highly skilled, and rotated duty stations and schedules multiple times per year (Dean 1998), making bias in any certain direction unlikely. Using two independent datasets (from Fowey and Carysfort) also safeguards against any systematic bias at a single lighthouse. The data reported here are from the published tables in Vaughan (1918) and are also available in the electronic supplementary material (Online Resource 1).

Ironically, it was the recognition of cold water stress as a major driver of coral mortality and sub-lethal reductions in coral growth (Hudson et al. 1976) that motivated the initiation of underwater temperature monitoring in the Florida Keys. Hudson (1981a) conducted a coral transplantation study in 1975 that included one of the first deployments of underwater "temperature loggers." These loggers (General Oceanics model \#3011) consisted of 8-mm cameras in housings that were set to take hourly photographs of a wristwatch and a dial read-out Fahrenheit thermometer. Hudson and colleagues established four permanent sites for monitoring underwater temperature in the upper Florida Keys (Hudson et al. 1991), including three 
sites along an on- to offshore transect from Snake Creek tidal channel in Islamorada, FL, to the outer-shelf reef at Crocker Reef. From 1975 to 1990, data (Online Resource 2) were gathered using this method, including regular calibration at intervals of 120 days or less (Hudson et al. 1991). Starting in 1990, Ryan Industries, Inc., thermographs were deployed at those sites and at additional strategic locations along the Florida reef tract. Later, Sea-Bird Electronics, Inc., thermographs were gradually phased in such that 38 thermographs were deployed in total, completing a network of sensors from southern Broward County to the Dry Tortugas. The instruments used in this network were calibrated regularly by the manufacturers when they were sent in for battery changes. The digital data since 1990 are available on the National Oceanographic Data Center (NODC) Oceanographic Data Archive (http://www.nodc.noaa.gov/cgi-bin/OAS/prd/text/ query) and are easiest to locate by querying the data submitter's name, "Jeff Anderson." The dataset from Hen and Chickens Reef, located on the landward edge of Hawk Channel, is the most complete and longest record resulting from these efforts, and is analyzed here for the composite time period from 1975 to 2007 (Online Resource 2). The thermograph sensor at Hen and Chickens Reef was always placed in the same open-ended cavity within a Montastraea faveolata coral, $0.5 \mathrm{~m}$ above the seafloor, in approximately $4 \mathrm{~m}$ of water depth. We also used thermograph data from Carysfort Lighthouse (1990 to 2008) for comparison with the lighthouse keeper data taken at this same location a century earlier. The thermograph was strapped to a cross member of the lighthouse structure in $\sim 1$ m of water depth.

The SEAKEYS (Sustained Ecological Research Related to Management of the Florida Keys Seascape) Program, developed in the late 1980 s as a resource management framework for marine ecosystem research coordination and integration, was designed to encompass the geographic and timescales of natural phenomena and processes (Ogden et al. 1994). At the core of the program were six fixed, automated, solar-powered, satellite-linked monitoring stations deployed by the National Data Buoy Center (NDBC). The NOAA Coastal-Marine Automated Network (C-MAN) weather stations were enhanced for the program to measure oceanographic as well as standard meteorological parameters. Underwater sensors at 1- and 3-m depths measured temperature, salinity, and light. Enhanced C-MAN stations were installed during 1991-1992 at Fowey Rocks, Molasses Reef, Sombrero Key, and Sand Key Reef. For this study, we used the water temperature ("WTMP") data from the C-MAN station at Fowey Rocks (FWYF1; Online Resource 3), available online (http://www.ndbc.noaa.gov/), for comparison to the Fowey Rocks lighthouse keeper data taken a century earlier at the same location. The temperature sensor is fixed to the lighthouse iron support structure approximately $1 \mathrm{~m}$ below the water surface.

\section{Statistical Analyses}

All datasets were analyzed using the software Statistix (C version 10.0 (Analytical Software, Tallahassee, FL, USA). The NDBC (Fowey) and thermograph (Carysfort) data were compared to the Vaughn (1918) lighthouse keeper data using Student's $t$ tests for each month of the year. To adjust for the increased probability of type II error resulting from the number of $t$ tests performed, a more conservative cutoff for statistical significance was applied (Bonferroni adjustment: alpha =

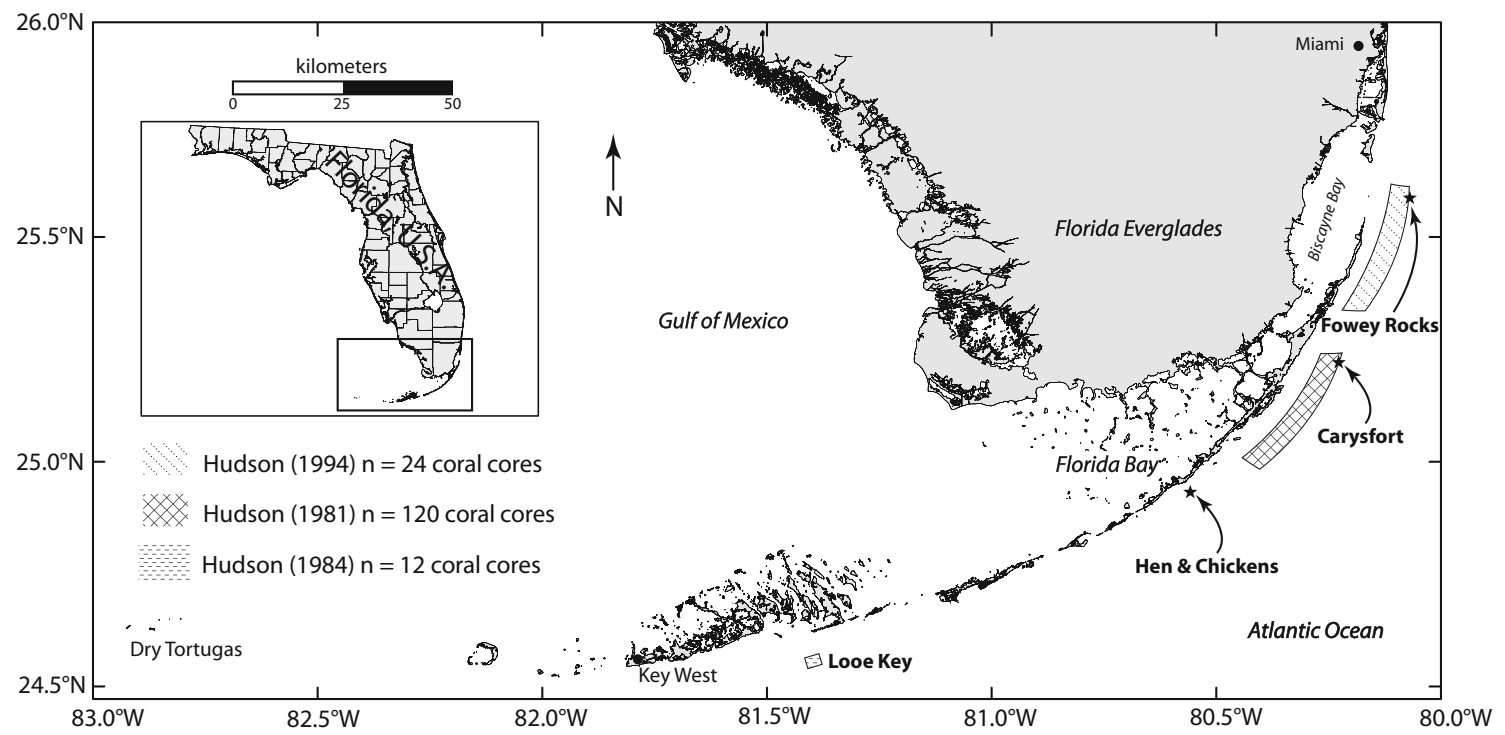

Fig. 1 Map of South Florida and the Florida Keys shows the location of several historic water temperature datasets (arrows). Also shown are reef areas where extensive sampling of live corals for growth studies occurred

in the 1970s and 1980s: Key Largo (Hudson 1981b), Looe Key (Hudson 1983), and Biscayne National Park (Hudson et al. 1994). Coral growth data from these publications are summarized in Fig. 5 
$0.05 / 12$ tests $=$ new $P$-value $<0.004)$. The Vaughn $(1918)$ data were reported in 35 10-day periods, with one remaining 15day period. We therefore averaged three 10-day periods to arrive at "monthly" means, leaving "December" with only 25 days. No supporting evidence for the unusually low temperature data in the Fowey record for 1902 and 1903 could be found in air temperature data for Miami or Key West, so data for those years were eliminated from the statistical analyses as a conservative measure. For the NDBC and thermograph data, hourly values were averaged to obtain daily data, and daily data were compiled to obtain monthly means. Since only one measurement was made per day by the lighthouse keepers, we included any day in the NDBC dataset for which there was at least one measurement. For the Hen and Chickens Reef dataset, hourly data were averaged for daily data, which were averaged for monthly data. Linear regression analyses were used to detect trends in mean monthly underwater temperature for each month of the year. We excluded any month from the datasets that was missing more than 3 days of measurements.

\section{Results}

Comparing the NDBC data at Fowey Rocks Light and the thermograph data at Carysfort Light to the lighthouse keeper data at their respective locations showed that water temperature on the northern Florida reef tract has increased over the last century (Figs. 2 and 3; Table 1). For Fowey Rocks, the months of June through December show statistically significant warming. If the estimates of warming for all of the months are averaged, the period from 1991 to 2012 was $\sim 0.8^{\circ} \mathrm{C}$ warmer than the earlier period (1879 to 1912). For Carysfort, the months of April through October show statistically significant warming. If the estimates of warming for all of the months are averaged, the later period (1990 to 2008) was $\sim 0.8^{\circ} \mathrm{C}$ warmer than the earlier period (1878 to 1899). Figure 3 shows that corals at Fowey Rocks and Carysfort Reef now spend July, August, and September in water temperatures averaging above $29^{\circ} \mathrm{C}$, whereas a century ago, the monthly average SST was at (August) or below (July and September)
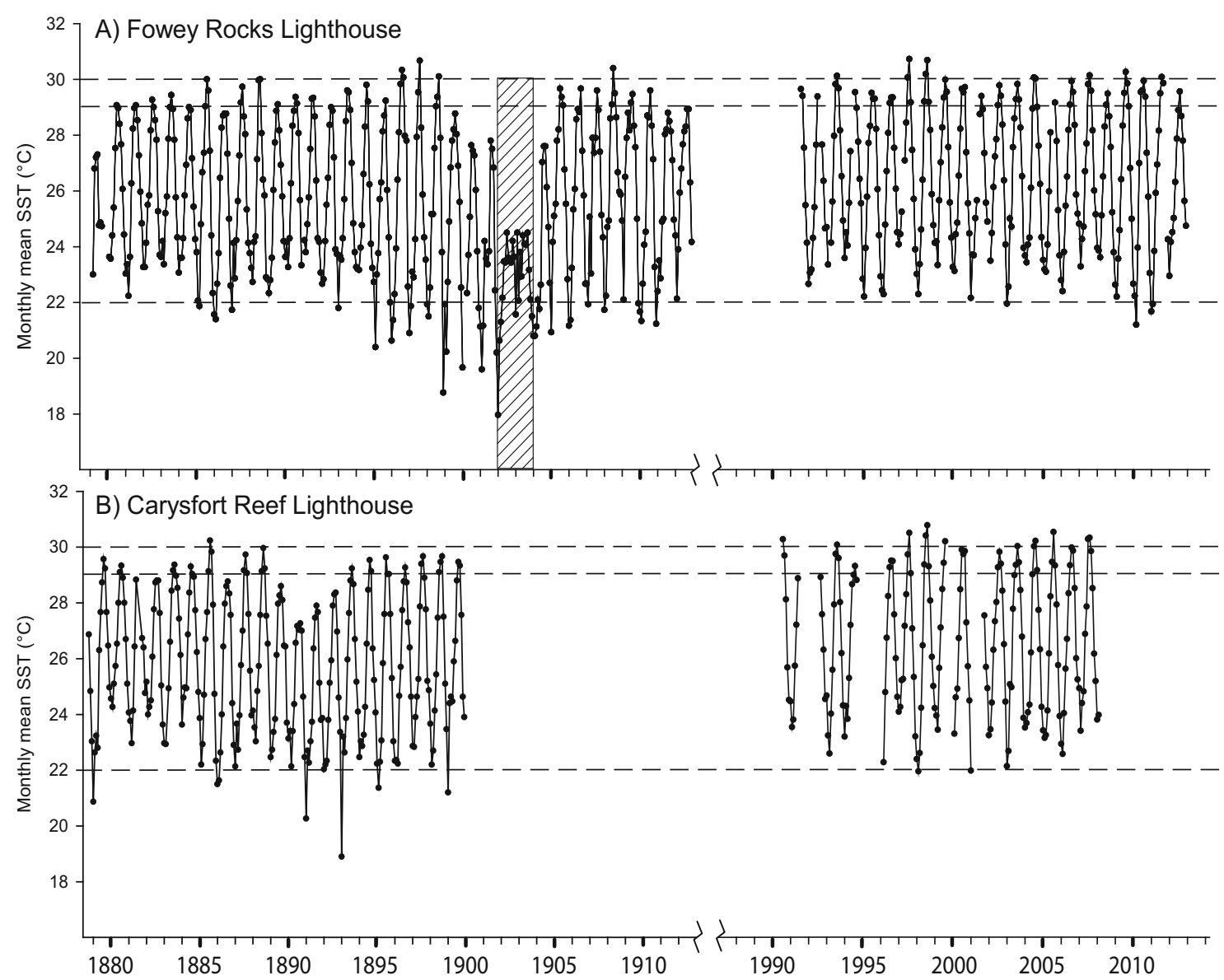

Fig. 2 Time series of monthly mean water temperature taken by lighthouse keepers in the late nineteenth and early twentieth centuries (Vaughan 1918) and by fixed sensors at the same locations a century later. No supporting evidence for the Fowey data in the shaded portion (1902 and 1903) could be found in air temperature data for Miami or Key
West, so these data were eliminated from the statistical analyses as a conservative measure. Dashed lines are for visual reference, marking the upper and lower boundaries within which coral growth is generally optimal 
Fig. 3 Comparisons of mean water temperature for two multidecadal time periods from the turn of the twentieth and twenty-first centuries at a Fowey Rocks Lighthouse and $\mathbf{b}$ Carysfort Reef Lighthouse. Error bars are \pm 1 SE, where $n=$ the number of years with three or fewer days of data missing for that month. Dashed lines are for visual reference and correspond with temperatures known to be stressful $\left(29^{\circ} \mathrm{C}\right)$ and very stressful $\left(30^{\circ} \mathrm{C}\right)$ for many coral species
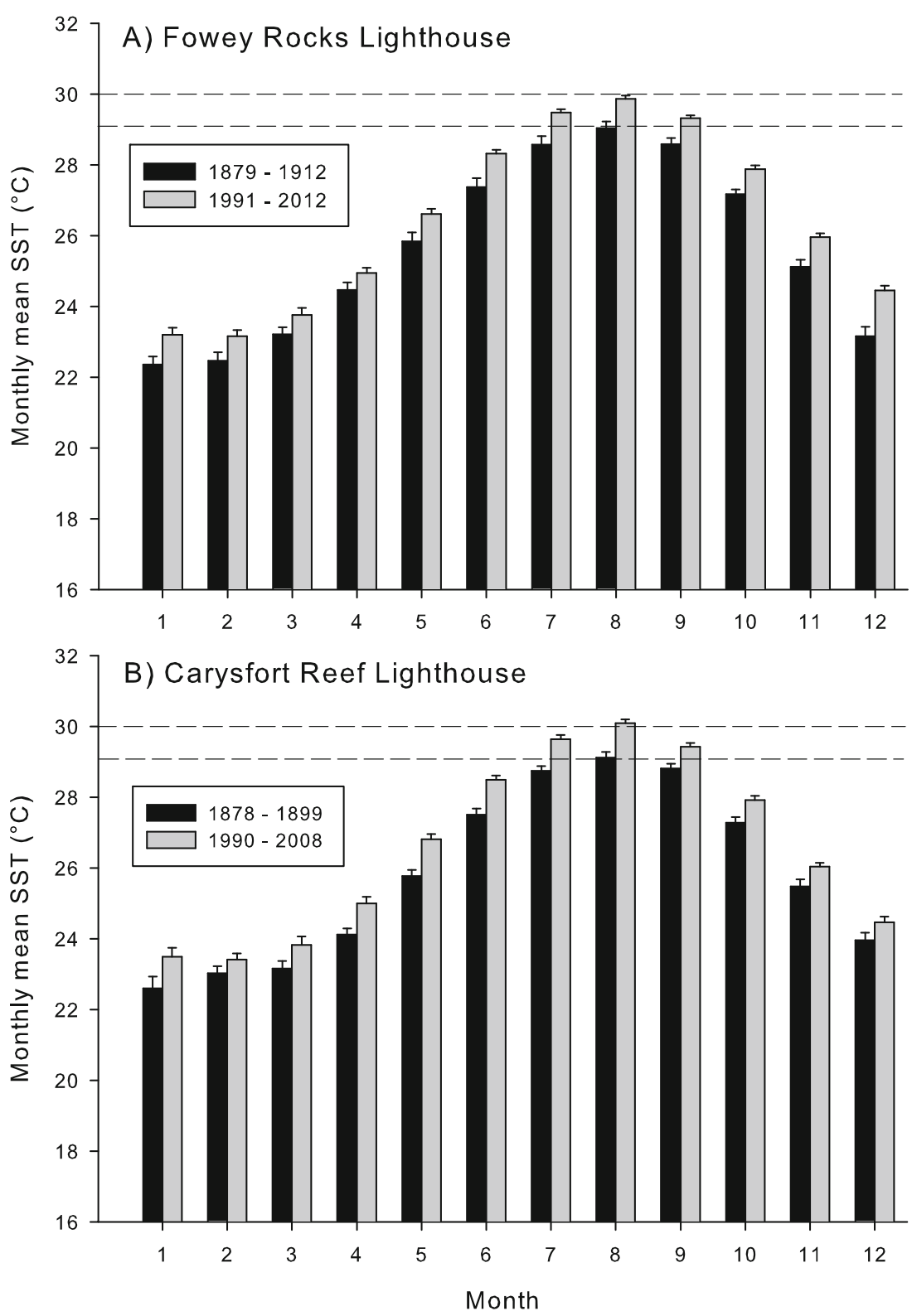

that value. The Pearson's correlation coefficient was 0.907 for the overlapping portions of the two lighthouse keeper datasets, and 0.997 for the NDBC FWYF1 and Carysfort Reef thermograph datasets.

Despite some gaps in the Hen and Chickens Reef underwater temperature time series, the 32-year record included enough months with complete measurements (ranged from 19 years for June to 23 years for January) to detect statistically significant trends in monthly mean temperature (Fig. 4). Analyses detected warming at the $P<0.05$ level for January, February, March, June, and August (Table 2). Only August showed warming at the Bonferroni-corrected $P<0.004$ level (Fig. 4b); however, since different years are included in each of the separate regressions, an argument could be made against necessity of the Bonferroni adjustment. If the reported slopes for each month's regression line are averaged, the estimated annual warming was $0.9{ }^{\circ} \mathrm{C}$ over the 32-year time period.

\section{Discussion}

The datasets analyzed here show $\sim 0.8^{\circ} \mathrm{C}$ of ocean warming for the Florida Keys outer-reef tract between the late $1870 \mathrm{~s}$ and the early $2000 \mathrm{~s}$ and $\sim 0.9{ }^{\circ} \mathrm{C}$ of warming at Hen and Chickens in-shore patch reef from 1975 to 2007. These are three independent lines of evidence demonstrating statistically robust, local-scale warming despite a great amount of intraand inter-annual variability in ocean temperature (Fig. 2). These results are in general agreement with the slow, fluctuating rate of warming observed in global surface temperature 
Table 1 Sea surface temperature (SST) collected by lighthouse keepers (century 1) compared to National Data Buoy Center (NDBC) fixedsensor SST (FWYF1; century 2) at Fowey Rocks Lighthouse and thermograph SST (century 2) at Carysfort Lighthouse, respectively. $P$-values are reported for two-sample Student's $t$ tests comparing the centuries. For tests where variance was unequal, a $P$-value is reported (in italics) using Satterthwaite's method assuming unequal variance. $P$-values $<0.004$ are in bold, denoting statistical significance as per the Bonferroni adjustment

\begin{tabular}{|c|c|c|c|c|c|c|c|c|c|c|c|}
\hline \multirow[t]{2}{*}{ Month } & \multirow[t]{2}{*}{ Century } & \multicolumn{5}{|c|}{ Fowey: lighthouse keeper vs. FWYF1 } & \multicolumn{5}{|c|}{ Carysfort: lighthouse keeper vs. thermograph } \\
\hline & & $N$ (years) & Mean SST $\left({ }^{\circ} \mathrm{C}\right)$ & $\operatorname{SE}\left({ }^{\circ} \mathrm{C}\right)$ & $P$-value & Warming $\left({ }^{\circ} \mathrm{C}\right)$ & $N$ (years) & Mean SST $\left({ }^{\circ} \mathrm{C}\right)$ & $\mathrm{SE}\left({ }^{\circ} \mathrm{C}\right)$ & $P$-value & Warming $\left({ }^{\circ} \mathrm{C}\right)$ \\
\hline \multirow[t]{2}{*}{ JAN } & 1 & 29 & 22.3 & 0.23 & & & 21 & 22.6 & 0.33 & & \\
\hline & 2 & 20 & 23.2 & 0.19 & 0.006 & 0.9 & 14 & 23.5 & 0.25 & 0.038 & 0.9 \\
\hline \multirow[t]{2}{*}{ FEB } & 1 & 30 & 22.5 & 0.24 & & & 21 & 23.0 & 0.20 & & \\
\hline & 2 & 21 & 23.1 & 0.18 & 0.025 & 0.6 & 14 & 23.4 & 0.18 & 0.18 & 0.4 \\
\hline \multirow[t]{2}{*}{ MAR } & 1 & 31 & 23.2 & 0.20 & & & 20 & 23.2 & 0.21 & & \\
\hline & 2 & 20 & 23.7 & 0.20 & 0.076 & 0.5 & 14 & 23.8 & 0.24 & 0.044 & 0.6 \\
\hline \multirow[t]{2}{*}{ APR } & 1 & 32 & 24.5 & 0.21 & & & 21 & 24.1 & 0.16 & & \\
\hline & 2 & 20 & 24.9 & 0.14 & 0.064 & 0.4 & 14 & 25.0 & 0.19 & 0.0013 & 0.9 \\
\hline \multirow[t]{2}{*}{ MAY } & 1 & 32 & 25.8 & 0.26 & & & 21 & 25.8 & 0.18 & & \\
\hline & 2 & 21 & 26.6 & 0.14 & 0.011 & 0.8 & 14 & 26.8 & 0.15 & 0.0003 & 1.0 \\
\hline \multirow[t]{2}{*}{ JUN } & 1 & 32 & 27.4 & 0.25 & & & 21 & 27.5 & 0.16 & & \\
\hline & 2 & 19 & 28.3 & 0.11 & 0.001 & 0.9 & 14 & 28.5 & 0.12 & $<0.0001$ & 1.0 \\
\hline \multirow[t]{2}{*}{ JUL } & 1 & 32 & 28.6 & 0.24 & & & 20 & 28.7 & 0.14 & & \\
\hline & 2 & 19 & 29.5 & 0.09 & 0.001 & 0.9 & 13 & 29.6 & 0.12 & 0.0001 & 0.9 \\
\hline \multirow[t]{2}{*}{ AUG } & 1 & 32 & 29.0 & 0.18 & & & 20 & 29.1 & 0.17 & & \\
\hline & 2 & 20 & 29.9 & 0.09 & 0.0002 & 0.9 & 14 & 30.1 & 0.11 & $<0.0001$ & 1.0 \\
\hline \multirow[t]{2}{*}{ SEP } & 1 & 32 & 28.6 & 0.17 & & & 20 & 28.8 & 0.14 & & \\
\hline & 2 & 21 & 29.3 & 0.07 & 0.0002 & 0.7 & 14 & 29.4 & 0.10 & 0.0007 & 0.6 \\
\hline \multirow[t]{2}{*}{ OCT } & 1 & 31 & 27.2 & 0.13 & & & 22 & 27.3 & 0.15 & & \\
\hline & 2 & 21 & 27.9 & 0.10 & 0.0001 & 0.7 & 14 & 27.9 & 0.12 & 0.0028 & 0.6 \\
\hline \multirow[t]{2}{*}{ NOV } & 1 & 31 & 25.1 & 0.20 & & & 22 & 25.5 & 0.20 & & \\
\hline & 2 & 21 & 26.0 & 0.10 & 0.0005 & 0.9 & 14 & 26.0 & 0.10 & 0.018 & 0.5 \\
\hline \multirow[t]{2}{*}{ DEC } & 1 & 31 & 23.2 & 0.26 & & & 21 & 24.0 & 0.21 & & \\
\hline & 2 & 22 & 24.5 & 0.13 & 0.0001 & 1.3 & 14 & 24.5 & 0.15 & 0.055 & 0.5 \\
\hline
\end{tabular}

over the century before 1975 , followed by rapid $\left(\sim 0.2^{\circ} \mathrm{C}\right.$ per decade) warming from 1980 to 2005 (Hansen et al. 2006). SST, which is warming more slowly than air over land (Burrows et al. 2011), has shown warming of about $0.04{ }^{\circ} \mathrm{C}$ per decade from 1960 to 1999 in the North Atlantic (Gleckler et al. 2012). The closest fixed site, long-term dataset we know of to our sites is that of Winter et al. (1998) at La Parguera, Puerto Rico; the warming trend observed there in the summer maximum SST, from 1966 to 1995 , was $0.7^{\circ} \mathrm{C}$. Additionally, Sheppard and Loughland (2002) found a remarkably similar $0.9^{\circ} \mathrm{C}$ warming in the subtropical Arabian Gulf from 1980 to 2000.

Of particular significance to corals, the months of July, August, and September all showed statistically significant warming at Fowey Rocks and Carysfort Reef, and August showed statistically significant warming at Hen and Chickens Reef. Temperature stress and risk of coral bleaching are most acute during the months when annual temperatures peak (Jokiel and Coles 1990), and indeed
August was the month with the highest mean SST in all five datasets analyzed here. The timing of bleaching episodes observed in the Florida Keys between 1989 and 2005 was well explained by maximum monthly mean SST and by the number of days that water temperature was above $30.5{ }^{\circ} \mathrm{C}$ (Manzello et al. 2007), and the frequency of bleaching events reported increased over this time period (Oliver et al. 2009).

High-temperature anomalies are not the only cause of temperature stress on corals. Common in subtropical waters, winter cold fronts can have major influences on coral survival and the distribution of coral populations in the Florida Keys (Porter et al. 1982). In January 2010, a severe cold front resulted in nearshore SST below $15{ }^{\circ} \mathrm{C}$ for multiple days, causing catastrophic mortality of corals on inshore patch reefs in the Florida Keys (Lirman et al. 2011; Colella et al. 2012). However, no mortality was observed during this event on the outer-reef tract. The winter months of December, January, February, and March showed warming in the datasets 
Fig. 4 Underwater temperature data for Hen and Chickens Reef off of Islamorada, FL, USA from 1975 to 2007. a Time series plot. b Mean monthly temperature during August. The line is derived from a simple linear regression. Dashed lines are for visual reference and correspond with temperatures known to be stressful $\left(29^{\circ} \mathrm{C}\right)$ and very stressful $\left(30^{\circ} \mathrm{C}\right)$ for many coral species
Table 2 Hen and Chickens Reef underwater $(\approx 4$-m depth) temperature, 1975 to 2007. Results are reported for the linear regression of monthly means vs. time (years). The plus symbol indicates a statistically significant warming trend, and the $P$-value is the probability that the trend could be due to chance alone. $P$-values at or less than $5 \%$ are in italic. The equal symbol indicates that there was not a significant trend detected
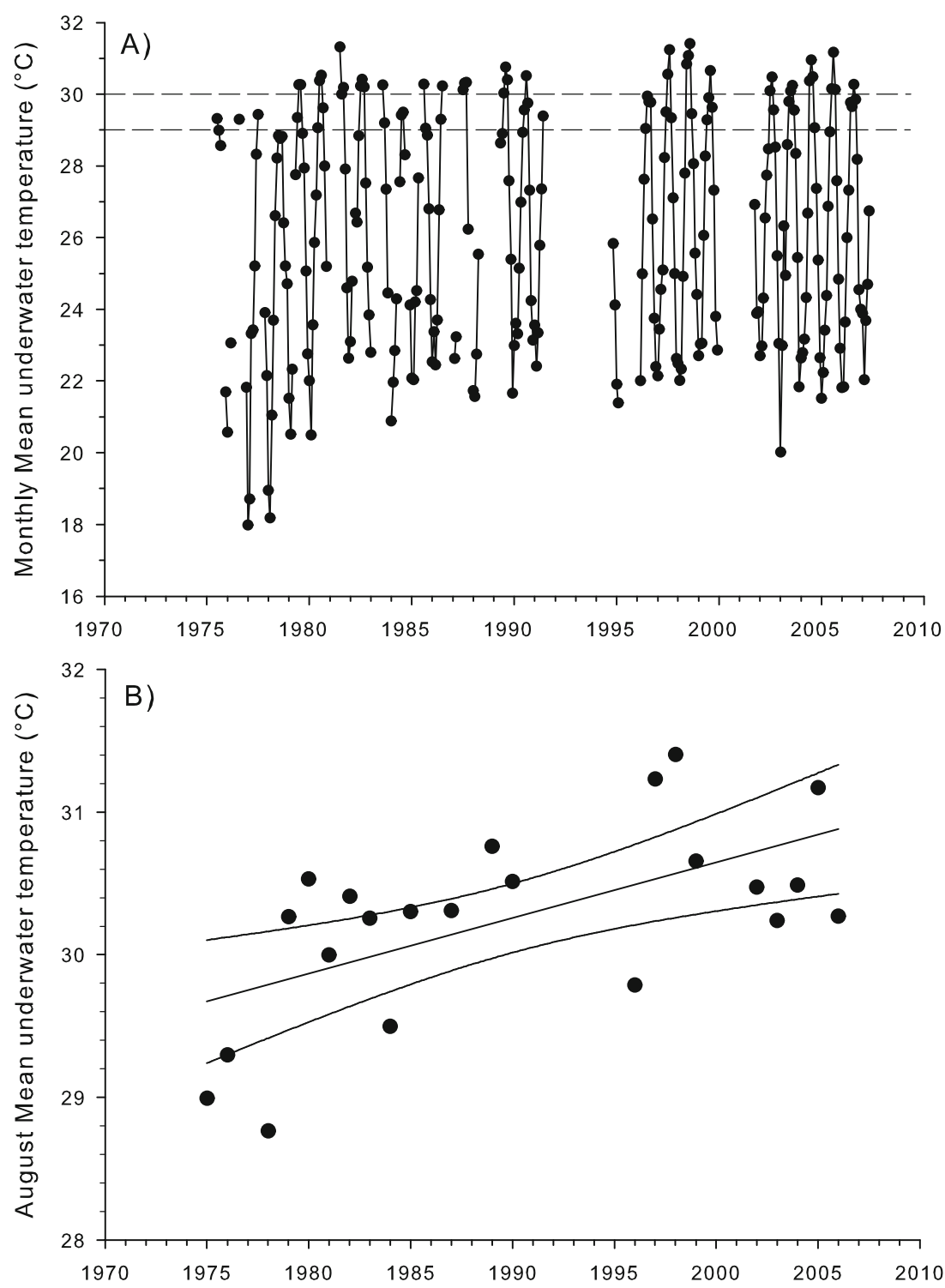

\begin{tabular}{llllll}
\hline Month & $N$ (years) & Trend & $P$-value & $\begin{array}{l}\text { Slope } \\
\left({ }^{\circ} \text { C year }{ }^{-1}\right)\end{array}$ & $\begin{array}{l}\text { Estimated } \\
\text { warming }\left({ }^{\circ} \mathrm{C}\right)\end{array}$ \\
\hline Jan & 23 & + & 0.05 & 0.055 & 1.8 \\
Feb & 22 & + & 0.04 & 0.067 & 2.1 \\
Mar & 22 & + & 0.05 & 0.043 & 1.4 \\
Apr & 20 & $=$ & 0.31 & 0.022 & 0.7 \\
May & 20 & $=$ & 0.15 & 0.027 & 0.9 \\
Jun & 19 & + & 0.02 & 0.041 & 1.3 \\
Jul & 21 & $=$ & 0.18 & 0.018 & 0.6 \\
Aug & 22 & + & 0.003 & 0.039 & 1.2 \\
Sep & 21 & $=$ & 0.16 & 0.018 & 0.6 \\
Oct & 20 & $=$ & 0.57 & 0.010 & 0.3 \\
Nov & 21 & $=$ & 0.81 & -0.004 & -0.1 \\
Dec & 22 & $=$ & 0.60 & 0.011 & 0.4 \\
\hline
\end{tabular}


presented here, but due to inherently higher variability of temperatures during winter, comparisons for these months were not as statistically robust. Interestingly, a winter cooling trend was observed in satellite SST data for waters around Florida (including Florida Bay) from 1985 to 2009 (Chollett et al. 2012). For the outer-reef tract though, biological evidence supports a winter warming trend in the form of the recently documented range expansion of the coral Acropora cervicornis northward into Broward County, FL (Precht and Aronson 2004). Corals in the genus Acropora are known to be very sensitive to low-temperature extremes (e.g., Shinn 1966). Similar poleward range expansions over the last several decades have been documented for multiple species of Acropora on the east coast of Australia (Baird et al. 2012) and in Japan (Yamano et al. 2011).

In general, coral growth (annual linear extension) rates in the tropics are found to be negatively correlated with annual mean SST, and this relationship is often used to reconstruct past sea surface temperature (Saenger et al. 2009; Cantin et al. 2010; Vasquez-Bedoya et al. 2012). However, manipulative experiments indicate a parabolic relationship between coral growth (calcification and/or linear extension) and SST (Jokiel and Coles 1977; Jokiel and Coles 1990), with highest growth rates found at temperatures 1 to $2{ }^{\circ} \mathrm{C}$ below the mean annual maximum. Thus, in subtropical regions, the relationship between coral growth and SST is complicated by the extreme seasonality in SST, and winter warming caused by global climate change could actually cause an increase in annual coral growth rates. Cooper et al. (2012) recently showed evidence for increased coral calcification rates at highlatitude reefs in Western Australia correlating with ocean warming, in contrast with a decrease found at low-latitude reefs. An investigation of trends in coral growth in the northern Florida Keys from 1937 to 1996 (using seven cores of
M. faveolata) did not find any trends (Helmle et al. 2011). Interestingly, that study also reported no warming trend in the Had1SST gridded data at that location during that time period. In Fig. 5, we summarize the results of three well-replicated, previously published coral growth studies conducted in the Florida Keys with M. faveolata (120 cores, Hudson 1981b; 12 cores, Hudson 1983; 24 cores, Hudson et al. 1994). The figure shows that coral growth at the three reefs has followed very different trajectories since around 1920, so these data do not support SST as a likely determinant of coral linear extension rates for this species in the Florida Keys. Incidentally, the 1910s and 1920s constituted a period of major land use change in South Florida, including the completion of the Overseas Railroad, stretching from Miami to Key West, the construction of which involved engineering many artificial land bridges connecting islands in the chain, as well as the "re-plumbing" of the Florida Everglades. Earlier work identified these land use changes in coral growth and skeletal fluorescence records (Hudson et al. 1989; Smith et al. 1989). Since those coring studies (Fig. 5) were completed by the early 1980s, it is unknown at this time whether or how coral growth responded to the rapid warming identified here in the Hen and Chickens underwater temperature dataset from 1975 to 2007. While the cores of Hudson et al. (Hudson 1981b; Hudson 1983; Hudson et al. 1994) constitute an extremely valuable archive that can be used for future studies including paleoreconstruction of environmental variables in the Florida Keys, new cores will be necessary to assess coral growth trajectory in the recent decades marked by accelerated warming. Surprisingly, we cannot even pinpoint the environmental variables responsible for differential calcification rates observed on today's reefs in the Florida Keys (Kuffner et al. 2013), so there is still much to learn about this fundamental process.
Fig. 5 Graphical summary of M. faveolata growth (mean annual linear extension) measured from X-rays of coral cores taken from three areas of the Florida reef tract (Hudson 1981b; Hudson 1983; Hudson et al. 1994). Locations of coring expeditions are included in Fig. 1. Error bars $\operatorname{are} \pm 1 \mathrm{SE}$

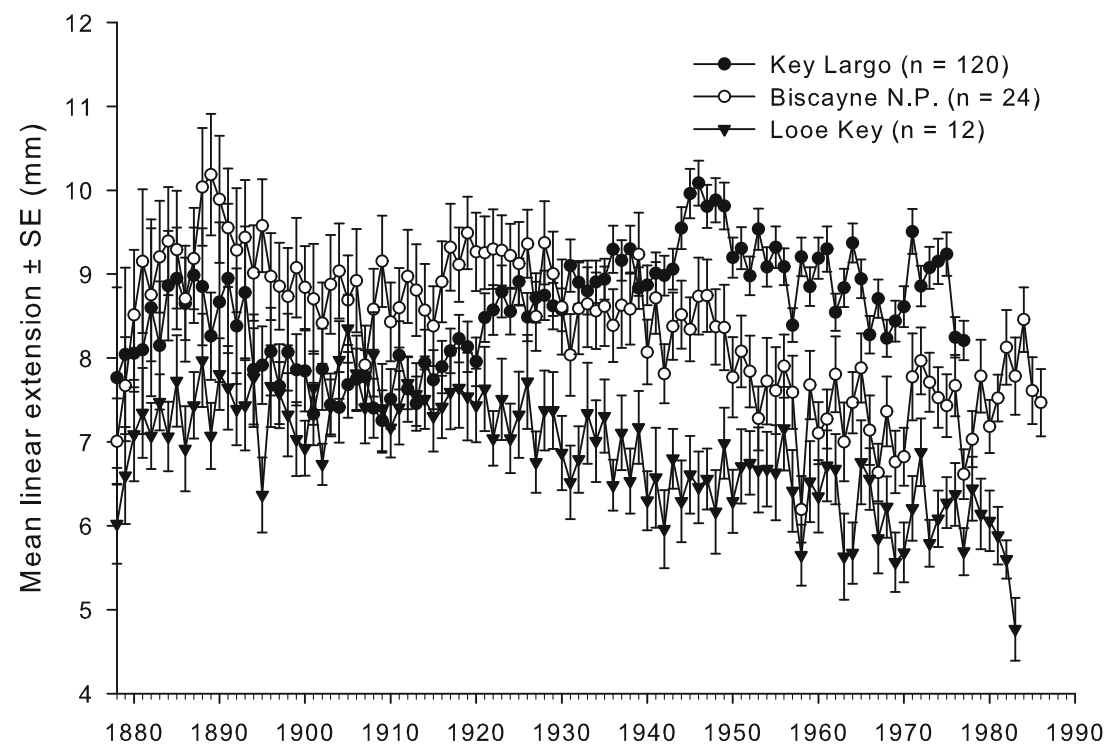


With the goal of understanding and predicting the impacts of anthropogenic warming in the context of natural temperature variability, coral chronology research needs to progress from using only coral growth records, which are clearly responsive to other variables in addition to SST. Using paleoreconstruction techniques such as trace metal and isotope proxies has proven useful (Druffel 1997), and recent methodological improvements allowing sub-annual resolution of the record are opening up further opportunity to obtain temperature records dating before the 1870 s and into the Holocene fossil record (e.g., Flannery and Poore 2013). Since mean linear extension does not track mean annual temperature in the Florida Keys very well, as explained earlier, geochemical proxies are a more robust way to reconstruct temperature for this subtropical region. Preliminary results using trace metal proxies show some evidence for recent ( 1970 to 1995) warming (Flannery and Poore 2013), but greater replication and longer records are desirable. Given the discrepancies among satellite-derived data, gridded data products like HadSST1, and in situ data (Leichter et al. 2006; Castillo and Lima 2010), we propose that in situ data are best for calibration of paleoproxies, especially for shallow, nearshore waters in subtropical regions.

\section{Geologic Context of Recent Climate Change}

As mankind continues to accelerate the redistribution of carbon on Earth, some researchers predict dire consequences for coral reef ecosystems on a global scale. As a result of the combined effects of ocean warming and acidification, they warn of a near complete loss of reefs and their ecosystem services by the middle of the twenty-first century (HoeghGuldberg et al. 2007; van Hooidonk et al. 2013). Since acute temperature stress causes coral mortality, whereas ocean acidification (OA) is expected to cause only sub-lethal declines in calcification rates, ocean warming will likely continue as the main climate-change-related cause of reef decline. The stress agents causing coral loss, however, do not have to be the same as those preventing the recovery of reefs, and this is where OA could play a main role, because of its effects on early life history stages of corals (Cohen et al. 2009; Albright et al. 2010) and the crustose coralline algae (CCA) they depend on for settlement (Kuffner et al. 2008). It is important to consider OA in the proper context, though; ecosystem metabolism and watershed processes exert strong, and sometimes overriding, effects on coastal $\mathrm{pH}$, and presently we only have evidence for $\mathrm{pH}$ declines from OA in the open ocean (Duarte et al. 2013).

The data presented in this paper provide empirical evidence that ocean waters around Florida reefs have warmed since the turn of the last century. It remains to be determined if this geologically short period of warming represents a lasting departure from the range in temperatures observed during the Holocene and whether or not the rate of warming has precedence in the fossil record. In the Gulf of Mexico (GOM), the early Holocene was characterized by high variability in SST, and there is evidence of a $1.5-^{\circ} \mathrm{C}$ warming over 200 years (LoDico et al. 2006), with periods of time throughout the Holocene being warm or warmer than modern times (Poore et al. 2003; Richey et al. 2007). The temperaturesensitive coral Acropora palmata built the Flower Garden Banks in the northwest GOM between 10,000 and 6,800 calibrated years before present, likely taking advantage of warmer winters (Precht et al. 2014). Sample resolution in the geologic record is not presently adequate to assess whether summer SSTs, specifically, were warmer than modern. If they were, it would be very instructive to know if reefs of the early and mid-Holocene suffered decreased growth rates and/or mortality from coral bleaching. With the accuracy and resolution of new paleoproxies increasing all the time, the scientific community is well poised to address these uncertainties.

\section{Prognosis for Florida Reefs}

Change in community structure (loss of corals) is the dominant driver resulting in negative carbonate budgets on reefs (Perry et al. 2013). Given its present state of low (less than $10 \%$ ) coral cover, the prognosis for reef building along the Florida reef tract is not a good one. However, the Florida Keys reefs have not been keeping up with sea level for the past 6,000 years. Only in the Dry Tortugas, the western terminus of the reef system, are Florida Holocene reefs thicker than a few meters (Shinn et al. 1977). Punctuated growth and regional demise of reefs throughout the Holocene geologic record are not unique to Florida. Periods of reef collapse pre-dating anthropogenic climate change were attributed to subtle changes in sea level (Florida: Lidz and Shinn 1991; Great Barrier Reef: Perry and Smithers 2011) and shifts in climatology (Eastern Pacific: Toth et al. 2012).

The few reefs that were accreting in the main Keys during the past century were dominated by large $A$. palmata stands, which experienced major declines in the early 1980 s resulting from coral disease. Also, bleaching during the 1997/1998 El Niño and cold stress events (Colella et al. 2012) left the monitored reefs in the Keys with less than $5 \%$ coral cover (Ruzicka et al. 2013; Toth et al. 2014). The outer-reef tract off the middle Keys, in particular, has shown degradation as documented by an increased abundance of coral-derived particles in reef sediments comparing surveys in 1989 with those from mid-century surveys (Lidz and Hallock 2000; Lidz et al. 2006). Regardless of what combination of stressors caused this recent bout of degradation, anthropogenic climate change continuing on the trajectory set in the past few decades will likely prevent reef recovery in the near future. Hardbottom communities with small, scattered coral heads may persist, dominated by species that are more resistant than others to bleaching, disease, and cold water stress (e.g. Siderastrea 
siderea, Lirman et al. 2011; Burman et al. 2012). Recent apparent recovery of $A$. cervicornis populations in the Dry Tortugas (Lidz and Zawada 2013) and range expansion northward along the reef tract (Precht and Aronson 2004) indicate that this species could be a "winner" in some areas, provided that they are spared exposure to cold stress events (Shinn 1966). However, studying bioerosion (Hudson 1977) is likely to reveal the most information regarding just how long the Florida reef tract will continue to serve as habitat for fisheries and a protector of shorelines because reef accretion is clearly already negative in many areas.

Acknowledgments We thank the US Geological Survey for funding this work, starting with T.W. Vaughan in the early 1900s, then with J.H. Hudson from 1974 to 1990, B.H. Lidz from 1974 to present, and I.B. Kuffner from 2002 to present. The first and second authors specifically thank the USGS Coastal and Marine Geology Program. We thank J. Flannery, C. Reich, and J. Morrison for assistance with the figures, and two anonymous reviewers and E. Shinn for helpful comments on the manuscript. Any use of trade names herein is for descriptive purposes only and does not imply endorsement by the US Government.

Open Access This article is distributed under the terms of the Creative Commons Attribution License which permits any use, distribution, and reproduction in any medium, provided the original author(s) and the source are credited.

\section{References}

Albright, R., B. Mason, M. Miller, and C. Langdon. 2010. Ocean acidification compromises recruitment success of the threatened Caribbean coral Acropora palmata. Proceedings of the National Academy of Sciences of the United States of America 107: 2040020404.

Baird, A.H., B. Sommer, and J.S. Madin. 2012. Pole-ward range expansion of Acropora spp. along the east coast of Australia. Coral Reefs 31: 1063 .

Barnett, T.P., D.W. Pierce, K.M. AchutaRao, P.J. Gleckler, B.D. Santer, J.M. Gregory, and W.M. Washington. 2005. Penetration of human-induced warming into the world's oceans. Science 309: 284-287.

Burman, S.G., R.B. Aronson, and R. van Woesik. 2012. Biotic homogenization of coral assemblages along the Florida reef tract. Marine Ecology Progress Series 467: 89-96.

Burrows, M.T., D.S. Schoeman, L.B. Buckley, P. Moore, E.S. Poloczanska, K.M. Brander, C. Brown, J.F. Bruno, C.M. Duarte, B.S. Halpern, J. Holding, C.V. Kappel, W. Kiessling, M.I. O'Conner, J.M. Pandolfi, C. Parmesan, F.B. Schwing, W.J. Sydeman, and A.J. Richardson. 2011. The pace of shifting climate in marine and terrestrial ecosystems. Science 334: 652-655.

Cai, W., S. Borlace, M. Lengaigne, P. van Rensch, M. Collins, G. Vecchi, A. Timmermann, A. Satoso, M.J. McPhaden, L. Wu, M.H. England, G. Wang, E. Cuilyardi, and J. Fei-Fei. 2014. Increasing frequency of extreme El Niño events due to greenhouse warming. Nature Climate Change 4: 111-116.
Cantin, N.E., A.L. Cohen, K.B. Karnauskas, A.M. Tarrant, and D.C. McCorkle. 2010. Ocean warming slows coral growth in the Central Red Sea. Science 329: 322-325.

Castillo, K.D., and F.P. Lima. 2010. Comparison of in situ and satellite-derived (MODIS-Aqua/Terra) methods for assessing temperature on coral reefs. Limnology and Oceanography: Methods 8: 107-117.

Chollett, I., F.E. Muller-Karger, S.F. Heron, W. Skirving, and P.J. Mumby. 2012. Seasonal and spatial heterogeneity of recent sea surface temperature trends in the Caribbean Sea and southeast Gulf of Mexico. Marine Pollution Bulletin 64: 956-965.

Cohen, A.L., D.C. McCorkle, S. de Putron, G.A. Gaetani, and K.A. Rose. 2009. Morphological and compositional changes in the skeletons of new coral recruits reared in acidified seawater: insights into the biomineralization response to ocean acidification. Geochemistry, Geophysics, Geosystems 10: 1-12.

Colella, M.A., R.R. Ruzicka, J.A. Kidney, J.M. Morrison, and V.B. Brinkhuis. 2012. Cold-water event of January 2010 results in catastrophic benthic mortality on patch reefs in the Florida Keys. Coral Reefs 31: 621-632.

Cooper, T.F., R.A. O'Leary, and J.M. Lough. 2012. Growth of Western Australian corals in the anthropocene. Science 335: 593-596.

Dean, L. 1998. Lighthouses of the Florida Keys. Sarasota, FL: Pineapple Press, Inc.

Druffel, E.R.M. 1997. Geochemistry of corals: proxies of past ocean chemistry, ocean circulation, and climate. Proceedings of the National Academy of Sciences of the United States of America 94: 8354-8361.

Duarte, C.M., I.E. Hendriks, T.S. Moore, Y.S. Olsen, A. Steckbauer, L. Ramajo, J. Carstensen, J.A. Trotter, and M. McCulloch. 2013. Is ocean acidification an open-ocean syndrome? Understanding anthropogenic impacts on seawater $\mathrm{pH}$. Estuaries and Coasts 36: 221-236.

Eakin, C.M., J.M. Lough, and S.F. Heron. 2009. Climate variability and change: monitoring data and evidence for increased coral bleaching stress. In Coral bleaching: patterns, processes, causes and consequences, ed. M.J.H. van Oppen and J.M. Lough, 41-67. Berlin: Springer.

Eakin, C.M., J.A. Morgan, S.F. Heron, T.B. Smith, G. Liu, L. AlvarezFilip, B. Baca, E. Bartels, C. Bastidas, C. Bouchon, M. Brandt, A.W. Bruckner, L. Bunkley-Williams, A. Cameron, B.D. Causey, M. Chiappone, T.R.L. Christensen, M.J.C. Crabbe, O. Day, E. de la Guardia, G. Diaz-Pulido, D. DiResta, D.L. Gil-Agudelo, D.S. Gilliam, R.N. Ginsburg, S. Gore, H.M. Guzman, J.C. Hendee, E.A. Hernandez-Delgado, E. Husain, C.F.G. Jeffrey, R.J. Jones, E. Jordan-Dahlgren, L.S. Kaufman, D.I. Kline, P.A. Kramer, J.C. Lang, D. Lirman, J. Mallela, C. Manfrino, J.-P. Marechal, K. Marks, J. Mihaly, W.J. Miller, E.M. Mueller, E.M. Muller, C.A. Orozco Toro, H.A. Oxenford, D. Ponce-Taylor, N. Quinn, K.B. Ritchie, S. Rodriguez, A. Rodriguez Ramirez, S. Ramano, J.F. Samhouri, J.A. Sanchez, G.P. Schmahl, B.V. Shank, W.J. Skirving, S.C.C. Steiner, E. Villamizar, S.M. Walsh, C. Walter, E. Weil, E.H. Williams, K. Woody Roberson, and Y. Yusuf. 2010. Caribbean corals in crisis: record thermal stress, bleaching, and mortality in 2005. PLoS ONE 5: e13969.

Flannery, J.A., and R.Z. Poore. 2013. Sr/Ca proxy sea-surface temperature reconstructions from modern and Holocene Montastraea faveolata specimens from the Dry Tortugas National Park. Journal of Coastal Research 63: 20-31.

Gleckler, P.J., B.D. Santer, C.M. Domingues, D.W. Pierce, T.P. Barnett, J.A. Church, K.E. Taylor, K.M. AchutaRao, T.P. Boyer, M. Ishii, and P.M. Caldwell. 2012. Human-induced global ocean warming on multidecadal timescales. Nature Climate Change 2: 524-529.

Glynn, P.W. 1983. Extensive 'bleaching' and death of reef corals on the Pacific coast of Panama. Environmental Conservation 10: 149-154. 
Good, S.A., G.K. Corlett, J.J. Remedios, E.J. Noyes, and D.T. LlewellynJones. 2007. The global trend in sea surface temperature from 20 years of advanced very high resolution radiometer data. Journal of Climate 20: 1255-1264.

Hansen, J., M. Sato, R. Ruedy, K. Lo, D.W. Lea, and M. Medina-Elizade. 2006. Global temperature change. Proceedings of the National Academy of Sciences of the United States of America 103: 14288 14293.

Helmle, K.P., R.E. Dodge, P.K. Swart, D.K. Gledhill, and C.M. Eakin. 2011. Growth rates of Florida corals from 1937 to 1996 and their response to climate change. Nature Communications 2: 215.

Hoegh-Guldberg, O., P.J. Mumby, A.J. Hooten, R.S. Steneck, P. Greenfield, E. Gomez, C.D. Harvell, P.F. Sale, A.J. Edwards, K. Caldeira, N. Knowlton, C.M. Eakin, R. Iglesias-Prieto, N. Muthiga, R.H. Bradbury, A. Dubi, and M.E. Hatziolos. 2007. Coral reefs under rapid climate change and ocean acidification. Science 318: $1737-1742$.

Honisch, B., A. Ridgwell, D.N. Schmidt, E. Thomas, S.J. Gibbs, A. Sluijs, R. Zeebe, L. Kump, R.C. Martindale, S.E. Greene, W. Kiessling, J.B. Reis, J.C. Zachos, D.L. Royer, S. Barker, T.M. Marchitto, R. Moyer, C. Pelejero, P. Ziveri, G.L. Foster, and B. Williams. 2012. The geological record of ocean acidification. Science 335: 1058-1063.

Hu, C., F. Muller-Karger, B. Murch, D. Myhre, J. Taylor, R. Luerssen, C. Moses, C. Zhang, L. Gramer, and J. Hendee. 2009. Building an automated integrated observing system to detect sea surface temperature anomaly events in the Florida Keys. IEEE Transactions of Geoscience and Remote Sensing 47: 1607-1620.

Hudson, J.H. 1977. Long-term bioerosion rates on a Florida reef: a new method. Proceedings of the 3rd International Coral Reef Symposium 2: 491-497.

Hudson, J.H. 1981a. Response of Montastrea annularis to environmental change in the Florida Keys. Proceedings of the 4th International Coral Reef Symposium 2: 233-240.

Hudson, J.H. 1981b. Growth rates in Montastraea annularis: a record of environmental change in Key Largo Coral Reef Marine Sanctuary, Florida. Bulletin of Marine Science 31: 444-459.

Hudson, J.H. 1983. Chapter 5: Growth history of Montastraea annularis at Looe Key National Marine Sanctuary, Florida. In: Resource survey of Looe Key National Marine Sanctuary, ed. J.A. Bohnsack, 91-111: NOAA Technical Memorandum NMFSSEFSC-478.

Hudson, J.H., E.A. Shinn, R.B. Halley, and B. Lidz. 1976. Sclerochronology: a tool for interpreting past environments. Geology 4: 361-364.

Hudson, J.H., G.V.N. Powell, M.B. Robblee, and T.J.I. Smith. 1989. A 107-year-old coral from Florida Bay: barometer of natural and maninduced catastrophies? Bulletin of Marine Science 44: 283-291.

Hudson, J.H., R.B. Halley, A.J. Joseph, B.H. Lidz, and D. Schroeder. 1991. Long-term thermograph records from the upper Florida Keys: US Geological Survey, Open-File Report 91-344.

Hudson, J.H., K.J. Hanson, R.B. Halley, and J.L. Kindinger. 1994. Environmental implications of growth rate changes in Montastrea annularis: Biscayne National Park, Florida. Bulletin of Marine Science 54: 647-669.

Jaap, W.C. 1979. Observations on zooxanthellae expulsion at Middle Sambo Reef, Florida Keys. Bulletin of Marine Science 29: 414-422.

Jokiel, P.L., and S.L. Coles. 1974. Effects of heated effluent on hermatypic corals at Kahe Point, Oahu. Pacific Science 28: 1-18.

Jokiel, P.L., and S.L. Coles. 1977. Effects of temperature on the mortality and growth of Hawaiian reef corals. Marine Biology 43: 201-208.

Jokiel, P.L., and S.L. Coles. 1990. Response of Hawaiian and other IndoPacific reef corals to elevated temperature. Coral Reefs 8: 155-162.

Kuffner, I.B., A.J. Andersson, P.L. Jokiel, K.S. Rodgers, and F.T. Mackenzie. 2008. Decreased abundance of crustose coralline algae due to ocean acidification. Nature Geoscience 1: 114-117.
Kuffner, I.B., T.D. Hickey, and J.M. Morrison. 2013. Calcification rates of the massive coral Siderastrea siderea and crustose coralline algae along the Florida Keys (USA) outer-reef tract. Coral Reefs 32: 987 997.

Leichter, J.J., B. Helmuth, and A.M. Fischer. 2006. Variation beneath the surface: quantifying complex thermal environments on coral reefs in the Caribbean, Bahamas and Florida. Journal of Marine Research 64: $563-588$.

Lidz, B.H., and P. Hallock. 2000. Sediment petrology of a declining reef ecosystem, Florida reef tract (U.S.A.). Journal of Coastal Research 16: 675-697.

Lidz, B.H., and E.A. Shinn. 1991. Paleoshorelines, reefs, and a rising sea: South Florida, U.S.A. Journal of Coastal Research 7: 203-229.

Lidz, B.H., and D.G. Zawada. 2013. Possible return of Acropora cervicornis at Pulaski Shoal, Dry Tortugas National Park, Florida. Journal of Coastal Research 29: 256-271.

Lidz, B.H., C.D. Reich, R.L. Peterson, and E.A. Shinn. 2006. New maps, new information: coral reefs of the Florida Keys. Journal of Coastal Research 22: 260-282.

Lirman, D., S. Schopmeyer, D. Manzello, L.J. Gramer, W.F. Precht, K. Banks, B. Barnes, E. Bartels, A. Bourque, J. Byrne, S. Donahue, J. Duquesnel, L. Fisher, D. Gilliam, J. Hendee, M. Johnson, K. Maxwell, E. McDevitt, J. Monty, D. Rueda, R. Ruzicka, and S. Thanner. 2011. Severe 2010 cold-water event caused unprecedented mortality to corals of the Florida reef tract and reversed previous survivorship patterns. PLOS ONE 6: e23047.

LoDico, J.M., B.P. Flower, and T.M. Quinn. 2006. Subcentennial-scale climatic and hydrologic variability in the Gulf of Mexico during the early Holocene. Paleoceanography 21, PA3015.

Mackenzie, F.T., and A. Lerman. 2006. Carbon in the geobiosphereEarth's outer shell. Dordrecht: Springer.

Manzello, D.P., R. Berkelmans, and J.C. Hendee. 2007. Coral bleaching indices and thresholds for the Florida Reef Tract, Bahamas, and St. Croix, US Virgin Islands. Marine Pollution Bulletin 54: 1923-1931.

Mayewski, P.A., E.E. Rohling, J.C. Stager, W. Karlen, K.A. Maasch, L.D. Meeker, E.A. Meyerson, F. Gasse, S. van Kreveld, K. Holmgren, J. Lee-Thorp, G. Rosqvist, F. Rack, M. Saubwasser, R.R. Schneider, and E.J. Steig. 2004. Holocene climate variability. Quaternary Research 62: 243-255.

Muscatine, L. 1990. The role of symbiotic algae in carbon and energy flux in reef corals. In Coral reefs, ecosystems of the world, ed. Z. Dubinsky, 75-87. Amsterdam: Elsevier Science.

Ogden, J.C., J.W. Porter, N.P. Smith, A.M. Szmant, W.C. Jaap, and D. Forcucci. 1994. A long-term interdisciplinary study of the Florida Keys seascape. Bulletin of Marine Science 54: 1059-1071.

Oliver, J.K., R. Berkelmans, and C.M. Eakin. 2009. Coral bleaching in space and time. In Coral bleaching: patterns, processes, causes and consequences, ed. M.J.H. van Oppen and J.M. Lough, 21-39. Berlin: Springer.

Parmesan, C. 2006. Ecological and evolutionary responses to recent climate change. Annual Review of Ecology, Evolution, and Systematics 37: 637-669.

Perry, C.T., and S.G. Smithers. 2011. Cycles of coral reef 'turn-on', rapid growth and 'turn-off' over the past 8500 years: a context for understanding modern ecological states and trajectories. Global Change Biology 17: 76-86.

Perry, C.T., G.N. Murphy, P.S. Kench, S.G. Smithers, E.N. Edinger, R.S. Steneck, and P.J. Mumby. 2013. Caribbean-wide decline in carbonate production threatens coral reef growth. Nature Communications 4: 1402. doi:10.1038/ncomms2409.

Pitts, P.A., and N.P. Smith. 1995. Air-water heat energy fluxes in the lower Florida Keys: fall and winter months. Bulletin of Marine Science 56: 767-777.

Poloczanska, E.S., C.J. Brown, W.J. Sydeman, W. Kiessling, D.S. Schoeman, P.J. Moore, K. Brander, J.F. Bruno, L.B. Buckley, M.T. Burrows, C. Duarte, B.S. Halpern, J. Holding, C.V. Kappel, M.I. 
O'Conner, J.M. Pandolfi, C. Parmesan, F. Schwing, S.A. Thompson, and A.J. Richardson. 2013. Global imprint of climate change on marine life. Nature Climate Change 3: 919-925.

Poore, R.Z., H.J. Dowsett, and S. Verado. 2003. Millennial- to centuryscale variability in Gulf of Mexico Holocene climate records. Paleoceanography 18: PA000868.

Porter, J.W., J.F. Battey, and G.J. Smith. 1982. Perturbation and change in coral reef communities. Proceedings of the National Academy of Sciences of the United States of America 79: 1678-1681.

Precht, W.F., and R.B. Aronson. 2004. Climate flickers and range shifts of reef corals. Frontiers in Ecology and the Environment 2: 307-314.

Precht, W.F., K.J.P. Deslarzes, E.L. Hickerson, G.P. Schmahl, M.F. Nuttall, and R.B. Aronson. 2014. Back to the future: the history of acroporid corals at the Flower Garden Banks, Gulf of Mexico, USA. Marine Geology 349: 152-161.

Richey, J.N., R.Z. Poore, B.P. Flower, and T.M. Quinn. 2007. 1400 yr multiproxy record of climate variability from the northern Gulf of Mexico. Geology 35: 423-426.

Roberts, H.H., L.J. Rouse Jr., N.D. Walker, and J.H. Hudson. 1982. Coldwater stress in Florida Bay and northern Bahamas: a product of winter cold-air outbreaks. Journal of Sedimentary Petrology 52: 0145-0155.

Ruzicka, R.R., M.A. Colella, J.W. Porter, J.M. Morrison, J.A. Kidney, V. Brinkhuis, K.S. Lunz, K.A. Macaulay, L.A. Bartlett, M.K. Meyers, and J. Colee. 2013. Temporal changes in benthic assemblages on Florida Keys reefs 11 years after the 1997/1998 El Niño. Marine Ecology Progress Series 489: 125-141.

Saenger, C., A.L. Cohen, D.W. Oppo, R.B. Halley, and J.E. Carilli. 2009. Surface-temperature trends and variability in the low-latitude North Atlantic since 1552. Nature Geoscience 2: 492-495.

Sheppard, C., and R. Loughland. 2002. Coral mortality and recovery in response to increasing temperature in the southern Arabian Gulf. Aquatic Ecosystem Health and Management 5: 395-402.

Shinn, E.A. 1966. Coral growth rate, an environmental indicator. Journal of Paleontology 40: 233-240.
Shinn, E.A., J.H. Hudson, R.B. Halley, and B. Lidz. 1977. Topographic control and accumulation rate of some Holocene coral reefs: South Florida and Dry Tortugas. Proceedings of the 3rd International Coral Reef Symposium 2: 1-7.

Smith, T.J., J.H. Hudson, M.B. Robblee, G.V.N. Powell, and P.J. Isdale. 1989. Freshwater flow from the Everglades to Florida Bay: a historical reconstruction based on fluorescent banding in the coral Solenastrea bournoni. Bulletin of Marine Science 44: 274-282.

Toth, L.T., R.B. Aronson, S.V. Vollmer, J.W. Hobbs, D.H. Urrego, H. Cheng, I.C. Enochs, D.J. Combosch, R. van Woesik, and I.G. Macintyre. 2012. ENSO drove 2500-year collapse of Eastern Pacific coral reefs. Science 337: 81-84.

Toth, L.T., R. van Woesik, T.J.T. Murdoch, S.R. Smith, J.C. Ogden, W.F. Precht, and R.B. Aronson. 2014. Do no-take reserves benefit Florida's corals? 14 years of change and stasis in the Florida Keys National Marine Sanctuary. Coral Reefs 33: 565-577.

van Hooidonk, R., J.A. Maynard, D. Manzello, and S. Planes. 2013. Opposite latitudinal gradient in projected ocean acidification and bleaching impacts on coral reefs. Global Change Biology 20: 103112.

Vasquez-Bedoya, L.F., A.L. Cohen, D.W. Oppo, and P. Blanchon. 2012. Corals record persistent multidecadal SST variability in the Atlantic Warm Pool since 1775 AD. Paleoceanography 27: PA3231.

Vaughan, T.W. 1918. The temperature of the Florida coral-reef tract. Carnegie Institute of Washington. Publication 9: 321-339.

Wilkinson, C., and G. Hodgson. 1999. Coral reefs and the 1997-1998 mass bleaching and mortality. Nature and Resources 35: 16-25.

Winter, A., R.S. Appeldoorn, A. Bruckner, E.H. Williams, and C. Goenaga. 1998. Sea surface temperatures and coral reef bleaching off La Parguera, Puerto Rico (northeastern Caribbean Sea). Coral Reefs 17: 377-382.

Yamano, H., K. Sugihara, and K. Nomura. 2011. Rapid poleward range expansion of tropical reef corals in response to rising sea surface temperature. Geophysical Research Letters 38: L04601. 